\title{
Sorting Nexin-18
}

National Cancer Institute

\section{Source}

National Cancer Institute. Sorting Nexin-18. NCI Thesaurus. Code C101746.

Sorting nexin-18 (628 aa, $96 \mathrm{kDa}$ ) is encoded by the human SNX18 gene. This protein is involved in both protein transport and endocytosis. 